\title{
Brazilian Public Controllership Institutions - Theory versus Practice
}

\author{
Janilson Antonio da Silva Suzart ${ }^{1}$, Carolina Venturini Marcelino ${ }^{2} \&$ Joseilton Silveira da Rocha $^{2}$ \\ ${ }^{1}$ University of São Paulo - USP, São Paulo, Brazil \\ ${ }^{2}$ University Federal of Bahia - UFBA, Salvador, Brazil \\ Correspondence: Janilson Antonio da Silva Suzart, University of São Paulo - USP, São Paulo, Brazil. E-mail: \\ suzart@suzart.cnt.br \& Carolina Venturini Marcelino, University Federal of Bahia - UFBA, Salvador, Brazil. \\ E-mail: carolinaventurini@ufba.br
}

Received: May 30, 2012

Accepted: August 6, 2012

Online Published: August 8, 2012

doi:10.5539/ibr.v5n9p184

URL: http://dx.doi.org/10.5539/ibr.v5n9p184

\begin{abstract}
The creation of a General Controllership (CGU) in the executive branch of the Brazilian federal government in 2003 brought in its wake the creation or transformation of a variety of institutions in public controllership at the state level. We have assumed that this development resulted from the needs of public managers for institutions that can not only monitor the actions taken by the public administration but also provide information useful to government managers, but this assumption needs to be tested. This article investigates whether the functions actually performed by the institutions of the Brazilian public controllership match the controllership functions defined in the literature. We studied a sample of 14 Brazilian public sector controllership institutions, one at the federal level and 13 at the state level. We found that in addition to contributing to the decision process, the studied public controllership institutions provided public managers with a means of monitoring the activities of public programs. Therefore, the data demonstrate that the functions performed by the institutions of Brazilian public controllership conform with the definitions of controllership functions found in the literature.
\end{abstract}

Keywords: controllership, public controllership, controllership functions, public administration

\section{Introduction}

The controllership plays an important role in day-to-day institutions. As both a public and private institution, the controllership helps develop strategies and objectives, elaborate budgets and standards, plan and implement decision models, manage institutions, and report results.

The institutions of the Brazilian public controllership developed within this context. The emergence of the General Comptroller of the Union (CGU, in Portuguese: Controladoria Geral da União) in January 2003 resulted in the creation or transformation of many institutions in the subnational governments. Although institutions called 'Comptroller General' have existed in the past, a model or a standardized concept of controllership did not exist in the Brazilian public sector until this point. The Brazilian government created a public controllership to help manage public resources by producing an instrument that can reduce the information asymmetry between managers and civil society.

However, in practice, have these institutions been able to achieve these goals? This issue stimulates the guiding question of this article: do the functions performed by the institutions of the Brazilian public controllership differ from those functions defined by the literature? To answer this question, this article tests the hypothesis that the two sets of functions differ from one another.

This article aims to contribute to the literature by analyzing the structure of and functions performed by Brazilian institutions for the public controllership. These institutions include one from the federal government and 13 from the subnational governments. The aim is to detect whether the functions, structures, and hierarchical positions of the public controllership are standardized and to compare these characteristics with those defined in the literature on the subject of the controllership. We tried to delimit the current frame of the controllership in the Brazilian public sector. Accordingly, this article aims to accomplish the following:

a. Describe the competences, constraints, subordination and organizational form of the Brazilian institutions for the public controllership. 
b. Identify the conditions that fostered the emergence of these institutions, especially in the subnational governments.

c. Check for the alignment of the characteristics of these institutions.

d. Study the functions assigned to the controllership by past researchers.

To achieve the objectives of this article, we started by analyzing legal documents (e.g., laws, decrees, and resolutions). Initially, we surveyed the information on the public controllership institutions being analyzed. After completely organizing the information, we performed a literature review to conduct the comparisons proposed in this paper.

\section{Controllership and Public Controllership}

\subsection{Controllership - Issues and Concepts}

Although the controllership's role appears to be similar to the role inhabited by financial accountants, in practice, its functions are quite different. The controllership helps improve an entity's future performance, signals the important aspects of the entity's activities, and anticipates the timely resolution of problems. In contrast, financial accountants only measure past performance. Green and Kaplan $(2004$, p. 3) describe both the controllership and the discipline of financial accounting in relation to the calculations, storage, and disclosure of information that ensure the entity's objectives will be achieved. As shown by the authors, the main difference between these areas is that the controllership is involved in providing direct support for future decisions.

However, what is the definition of the controllership? Borinelli (2006, p. 95) points out that the controllership can be defined from three different perspectives: as a science, as a set of organizational functions, and as an organizational unit.

In viewing the controllership as a science, Almeida, Parisi and Pereira $(1999$, p. 370) show that from the perspective of business knowledge, the controllership represents a set of multidisciplinary theoretical concepts based on accounting theory. Accordingly, the controllership defines, creates, and maintains information systems and management models to assist the decision-making process. In addition, Tung (1976, p. 11) points out that the controllership is a science responsible for investigating the goals and achievements of the entity from an economic point of view. The author adds that the controllership is not restricted to studies on the static accounting data, which encompass the planning, analysis, and control of the entity.

Some scholars also view the controllership as a set of organizational functions that relate to the conceptual aspects of the science defined by the controllership. Borinelli (2006, p. 125) shows that the literature uses several expressions to represent this perspective, such as functions, activities, responsibilities, and assignments. Different authors have presented different interpretations of these functions. Whereas Peleias (2002, p. 14) suggests that the functions of the controllership will vary depending on the specifics of the management model adopted by an organization, Borinelli (2006, p. 126) argues for the existence of a common core of functions that typify the controllership. In the next section, we will examine the functions considered as typical of the controllership in the literature.

Finally, some researchers view the controllership as an organizational unit. Almeida, Parisi, and Pereira (1999, p. 371) state that the controllership, as an administrative unit, is responsible for coordinating the efforts of other managers in optimizing organizational results through management technologies. Mosimann and Fisch (1999, p. 88) define the controllership as an organizational unit and administrative body whose mission and values are delineated by the model of organizational management. Crozatti (2003, p. 17) describes the controllership unit as responsible for the synergy among different areas, which it achieves by optimizing the economic results, the management of information systems, the provision of quantitative assessments, and the preparation of strategic planning.

\subsection{Typical Functions of the Controllership}

The day-to-day set of controllership functions is daunting given the diversity of concepts in the literature. Moreover, as mentioned earlier, the tasks of the controllership units are influenced by the virtues of the management structure and the model of the entities.

However, in this paper, we acknowledged that a set of common functions for the controllership exists. Hereafter, these functions are called the typical functions. Past authors have formulated different sets of typical functions, as shown below.

According to Willson, Roehl-Anderson, and Bragg (1997, p. 22-23), the following are typical functions of the controllership. The controllership develops an integrated operational plan in the short and long term that is in 
line with the objectives and goals of the institution; creates standards for assessing organizational performance and for comparing results; formulates, analyzes, and interprets reports that contain important information for the decision-making process; conducts financial, tax, and cost accounting, which specifically target the provision of key information in the decision-making process; and performs various complementary activities, such as answering requests for information by third parties.

Almeida, Parisi, and Pereira (1999, p. 376-377) point out that the controllership functions aim to facilitate the management process. These authors highlight the following functions. The controllership supports the management process by using an information system to assist the decision-making process; aids the performance analysis of areas, managers, and the entity itself; helps analyze and evaluate the results pertaining to the institution in all of its dimensions, which contributes to the development of standards; manages information systems by developing decision models and information models that provide management support; and undertakes activities to answer the demands of market agents (i.e., agents external to the organization).

According to Piai (2000, p. 20-25), the typical functions of the controllership are as follows. The controllership provides information (e.g., economic and financial situation, performance of sectors, and managers and organization) to support decision making; helps monitor and evaluate the performance and the results of an organization at all levels; formulates goals, defines scenarios, and coordinates an organization's planning of its activities; and develops information systems that assist in the organization of operations and in the early identification of these results.

Borinelli (2006, p. 135) describes the following features as typical of the controllership:

a. Accounting function: the controllership manages the activities undertaken by financial accounting;

b. Strategic management function: it conducts activities aimed at supporting decision making and the achievement of organizational goals);

c. Cost function: it conducts cost accounting activities;

d. Tax function: it manages tax accounting activities;

e. Protection and control of assets function: it safeguards the organization's assets;

f. Internal control function: it develops, implements, and monitors the internal control system;

g. Risk control function: it conducts risk management activities and discloses their effects; and

h. Information management function: it creates and models information systems of accounting, financial, economic, and management natures.

In this paper, we adopted Borinelli's approach because it encompasses the other concepts presented here. Thus, we compared the functions of the controllership institutions with Borinelli's set of functions.

\subsection{Public Controllership}

In a study on governance in the public sector, the International Federation of Accountants (2001, p. 1) states that the complexity of public entities hinders the development of universal recommendations. It shows that these entities must deal with complex political, economic, and social circumstances. This complexity appears to complicate the analysis and studies on other characteristics of the public sector.

However, the diversity in the public sector does not prevent the analysis of this sector and its themes, one of which is the controllership. According to Slomski (2007, p. 15), the controllership comprises "[...] the search for the optimal of any entity, whether public or private [...]." This 'optimal' comprises a higher result than the one expected by the entity. In this context, according to Scarpin and Slomski (2007, p. 916), the public or government controllership develops mechanisms to achieve this 'optimal.'

Solle (2003, p. 2) points out that from an operational viewpoint, the controllership aids the management of public entities. This author adds that its implementation requires a previous reflection about the mission and structure of the controllership unit. In support of this idea, Thompson and Jones $(1986$, p. 1) assert that in the public sector, the controllership primarily monitors the execution of the budget. Thus, the government sector that assists the management of public resources embodies the controllership, which may assume the form of a state entity's specific organ or be based on the performance of various sectors' and/or civil servants' activities.

Another important role of the public controllership is outcome assessment. According to Slomski (2001, p. 273), the controllership is the administrative body responsible for managing the entire information system and helping managers to correctly measure results. Peter, Cavalcante, Pessoa, Santos, and Peter (2003, p. 8) state that 
because the public controllership assumes the existence of a participatory, continuous, and integrated planning system, the public controllership must assess how the results from the management process have been achieved.

\section{Methodology}

In this section, we discuss the methodology used in this article and cover the description of the sample, the type and nature of the research, and the data analysis procedures.

The sample of this article comprises 14 Brazilian public sector institutions established by law at the federal and subnational levels. We selected only the institutions that have the words 'controllership' and 'comptroller' in their official designations. We found one federal institution and 13 subnational institutions. We conducted our analysis solely based on these institutions because we thought that the creation of a public entity dedicated to the controllership signifies the high level of importance given by the creator of public entities (the Union and States) to this area.

This work is supported by the following types of research: bibliographic, exploratory, and documental research. We developed the first type, bibliographic research, by consulting the national and international literature on the controllership to identify its key aspects and typical functions. The second type, exploratory research, was conducted because of the scarcity of material on the analyzed subject. Here, we sought to deepen the concepts not previously covered by the literature. We conducted the last type, documental research, by collecting legal documents dealing with the establishment, structure, hierarchy, and tasks of these institutions and by obtaining additional information from the institutions' websites.

We conducted the following procedures. First, we analyzed legal documents that established the characteristics of the studied public institutions. Second, we analyzed accessory documents that complemented the information on the controllership institutions. Third, we organized and tabulated the data collected. Fourth, we reviewed the literature on the controllership, particularly the functions that are related to it. Finally, we compared the information obtained in the analysis of the public controllership institutions with the findings obtained in the literature.

\section{Results}

This article focused on the institutions of the Brazilian federal and subnational public controllership. Thus, we collected information on 14 public controllership institutions, which are listed in Table 1 below. We showed that the other Brazilian subnational governments did not have a controllership entity according to the criteria specified in the methodology of this article.

Table 1. List of studied Brazilian public controllership institutions

\begin{tabular}{lllll}
\hline \multirow{2}{*}{ NAME } & \multirow{2}{*}{ ABBREVIATION } & \multirow{2}{*}{ TYPE } & \multicolumn{2}{c}{ CREATION } \\
\cline { 4 - 5 } & & & DATE & DOCUMENT \\
\hline Controladoria-Geral da União & CGU & Federal & $05 / 28 / 2003$ & Law n. 10.683 \\
ControladoriaGeral do Estado & CGE-AC & State & $08 / 31 / 2007$ & Law n. 171 \\
ControladoriaGeral do Estado & CGE-AL & State & $03 / 18 / 2003$ & Law n. 15 \\
ControladoriaGeral do Estado & CGE-AM & State & $06 / 09 / 2005$ & Law n. 3 \\
Secretaria da Controladoria e Ouvidoria Geral & SCOG-CE & State & $03 / 07 / 2003$ & Law n. 13.297 \\
Controladoria-Geral do Estado & CGE-MA & State & $01 / 31 / 2003$ & Law n. 7.844 \\
ControladoriaGeral do Estado & CGE-PB & State & $04 / 27 / 2005$ & Law n. 7.721 \\
Secretaria Especial da Controladoria Geral do Estado & SECGE-PE & State & $01 / 19 / 2007$ & Law n. 13.205 \\
ControladoriaGeral do Estado & CGE-PI & State & $06 / 09 / 2003$ & Law n. 28 \\
ControladoriaGeral do Estado & CGE-RN & State & $01 / 09 / 1997$ & Law n. 150 \\
ControladoriaGeral do Estado & CGE-RO & State & $06 / 22 / 1995$ & Law n. 133 \\
Controladoria-Geral do Estado & CGE-RR & State & $07 / 19 / 2005$ & Law n. 499 \\
ControladoriaGeral do Estado & CGE-SE & State & $01 / 09 / 1995$ & Law n. 3.591 \\
Controladoria-Geral do Estado & CGE-TO & State & $11 / 20 / 2003$ & Law n. 1.415 \\
\hline
\end{tabular}

Note: Reference year: 2008.

In a preliminary analysis of Table 1, we can see that most of the public controllership institutions were created in Brazil in 2003, as shown in Figure 1. Eight institutions were created, including the CGU. We also note that all of them have adopted the term 'General Controllership' or 'General Comptroller' (in Portuguese, 'ControladoriaGeral'). 


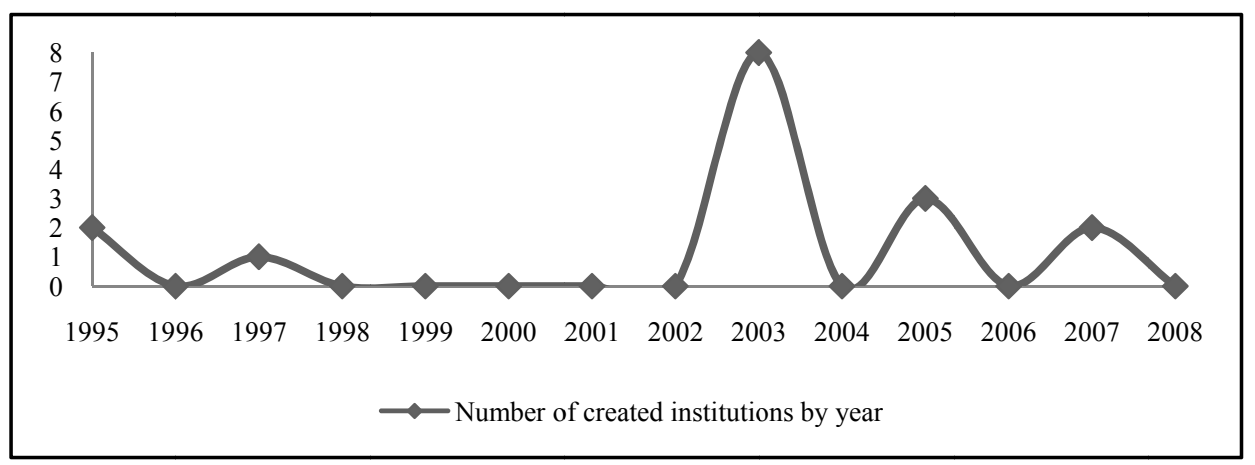

Figure 1. Number of created institutions from 1995 to July 2008

With respect to the hierarchy, we observed that all of these institutions were part of the executive branch and were located in the direct administration, as described in Table 2. No institutions were located in other branches, as occurs, for example, in the Judiciary in Mexico, where the Controllership of the Federal Judiciary exists (Consejo de la Judicatura Federal, 2008).

Table 2. Ancillary information about the institutions

\begin{tabular}{lllll}
\hline INSTITUTION & BRANCH & SUBORDINATION & CLASSIFICATION & MANAGER \\
\hline CGU & Executive & President & Ministry & Minister \\
CGE-AC & Executive & Governor & Autonomous & General Controller \\
CGE-AL & Executive & Governor & Autonomous & General Controller \\
CGE-AM & Executive & Governor & Autonomous & General Controller \\
SCOG-CE & Executive & Governor & Secretary & Secretary \\
CGE-MA & Executive & Governor & Secretary & General Auditor \\
CGE-PB & Executive & Governor & Secretary & Secretary \\
SECGE-PE & Executive & Governor & Secretary & Secretary \\
CGE-PI & Executive & Governor & Autonomous & General Controller \\
CGE-RN & Executive & Governor & Autonomous & General Controller \\
CGE-RO & Executive & Governor & Autonomous & General Controller \\
CGE-RR & Executive & Governor & Autonomous & General Controller \\
CGE-SE & Executive & Governor & Secretary & Secretary \\
CGE-TO & Executive & Governor & Secretary t & Secretary \\
\hline
\end{tabular}

Note: Reference year: 2008.

All institutions were considered subordinate to the Executive Chief (President/Governor). Half of these institutions were classified into the subnational law as Secretaries (in the case of GCU, as a Ministry), and the other half were classified as autonomous bodies. According to the title of the office responsible for the institution, $50 \%$ of the institutions were managed by the 'General Controllership' (see Figure 2).

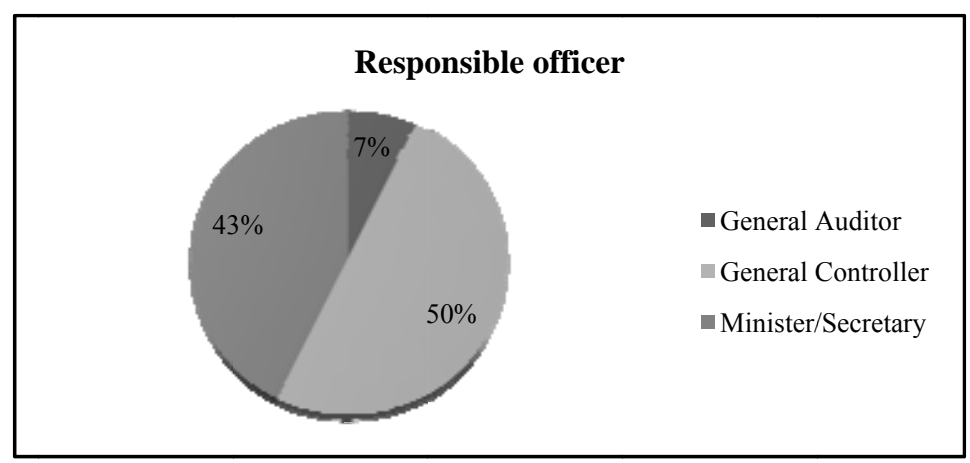

Figure 2. Title of the officer responsible for the institution 
Regarding the structure of these institutions, no standard appeared to exist. Although a clear separation existed between the sectors that performed secondary activities and those that performed primary activities in all of the analyzed institutions, we found that the only sector that existed in all of the institutions was 'Administration and Finance,' as can be seen in Figure 3. The structure of the CGU was not replicated in any other institution.

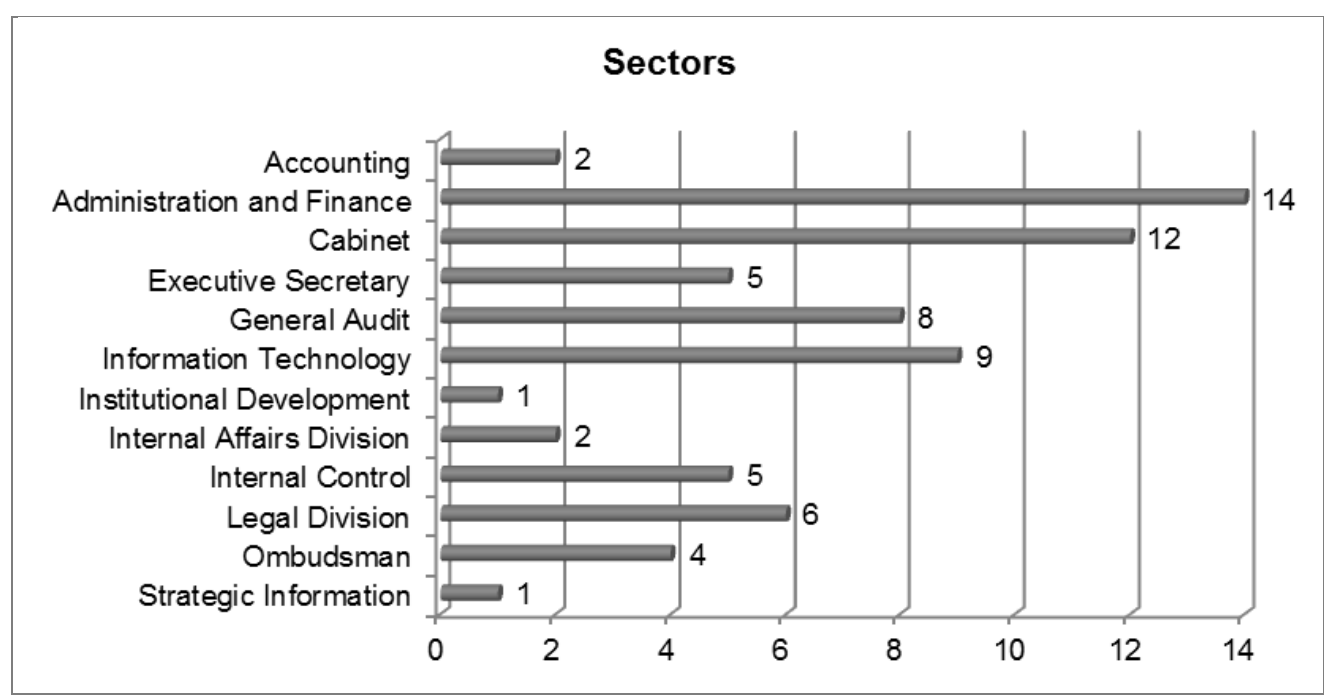

Figure 3. Structure of the institutions

In Figure 3, we noted that $85.7 \%$ of the institutions have a 'Cabinet,' which suggests that this feature was commonly found in the public administration, particularly those institutions classified as Secretaries. We showed that $64.3 \%$ of these institutions have an 'Information Technology' sector. We noted the existence of the 'General Audit,' which suggests that eight of these institutions emerged from the transformation of bodies and/or departmental audits.

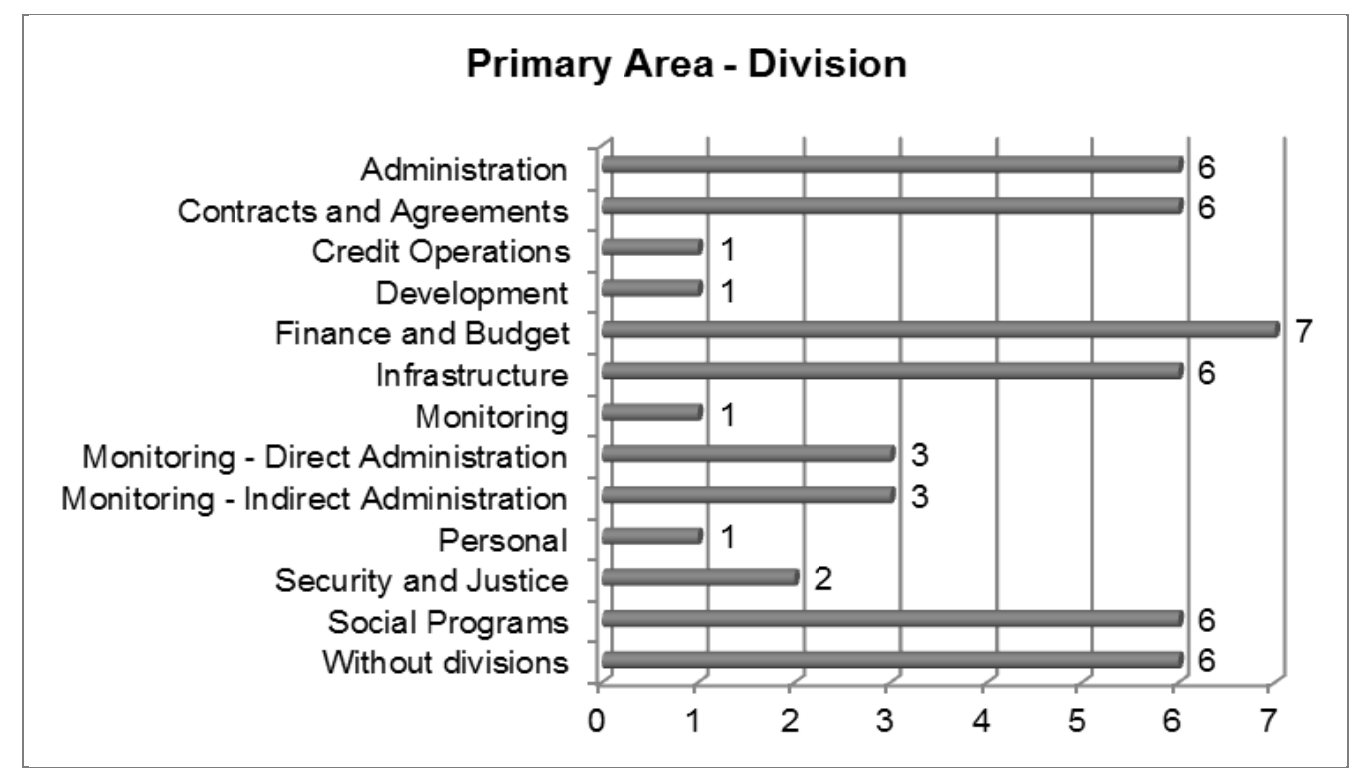

Figure 4. Division in the primary areas of the entities

In relation to the subdivision of the sectors related to the primary activities, we found that six of these institutions did not subdivide these sectors into specific departments (see Figure 4). Only three institutions divided them according to the classification of the public entity, that is, whether the unit belonged to the direct or indirect administration. In the other institutions, five divisions were important: 'Administration,' 'Contracts and Agreements,' 'Finance and Budget,' 'Infrastructure,' and 'Social Programs.' 
Table 3. Information about the entities' websites

\begin{tabular}{llllll}
\hline \multirow{2}{*}{ INSTITUTION } & DOES & THE INSTITUTION & & CONTENT & DOES THE WEBSITE HAVE A \\
& HAVE ITS OWN WEBSITE? & MISSION & VISION & 'TRANSPARENCY PORTAL'? \\
\hline CGU & Yes & No & No & No \\
CGE-AC & No & No & No & Yes \\
CGE-AL & Yes & Yes & No & No \\
CGE-AM & Yes & No & No & Yes \\
SCOG-CE & Yes & Yes & Yes & No \\
CGE-MA & Yes & Yes & No & No \\
CGE-PB & Yes & Yes & No & Yes \\
SECGE-PE & No & No & No & No \\
CGE-PI & Yes & No & No & No \\
CGE-RN & Yes & Yes & No & No \\
CGE-RO & No & No & No & No \\
CGE-RR & Yes & No & Yes & No \\
CGE-SE & Yes & Yes & No & \\
CGE-TO & Yes & No & & & \\
\hline
\end{tabular}

Note: Reference year: 2008.

To complement the information on these institutions, we analyzed the websites of these institutions or the websites of institutions related to the public controllership. Only three institutions did not have sites. However, those that had websites posted some content about the institutions and their activities.

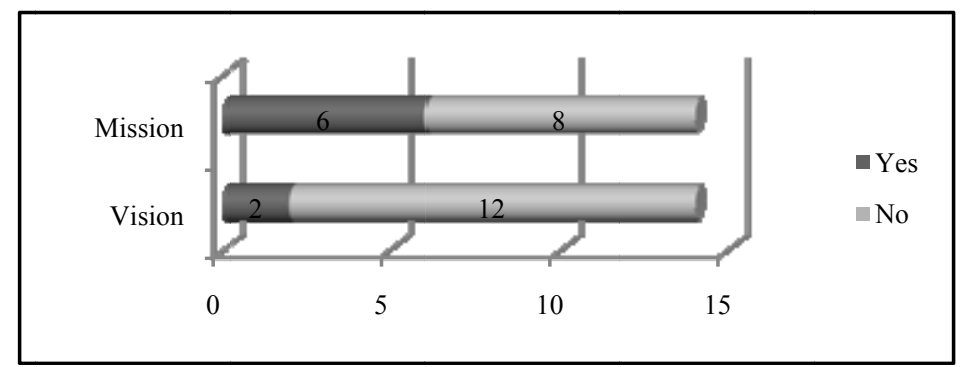

Figure 5. Disclosure of the mission and vision at the site of the institution

According to the data shown in Figure 5, few institutions disseminated information about their missions and visions. Only six sites from the controllership institutions described their missions, and two reported the visions of the institutions. With respect to the disclosure of the missions, we found that the main ideas of the missions related to the internal control and supervision of public resource management (see Table 4).

Table 4. Missions of the public controllership institutions

\begin{tabular}{ll}
\hline INSTITUTION & MISSION \\
\hline CGE-AL & $\begin{array}{l}\text { Effecting permanent internal control of the government's management to anticipate, minimize, and correct illegalities, } \\
\text { improprieties, or nonconformities in the acts committed by public officials; facilitating and conducting activities to } \\
\text { enhance legitimacy; and achieving tangible outcomes and societal aspirations. }\end{array}$ \\
\hline SCOG-CE & $\begin{array}{l}\text { Ensuring quality and regularity in the use of public resources, promoting the link between society and government } \\
\text { actions, and contributing to the welfare of Ceará. }\end{array}$ \\
\hline CGE-MA & $\begin{array}{l}\text { Ensuring regular and effective management of public resources in harmony with social control for the benefit of } \\
\text { Maranhão. }\end{array}$ \\
\hline CGE-PB & $\begin{array}{l}\text { Monitoring, evaluating, examining, guiding, and controlling the organs of the State Executive Branch to maximize the } \\
\text { performance and quality of public management, with an emphasis on results and in compliance with legal requirements; } \\
\text { and using qualified staff and efficient and effective techniques with technological support aimed at optimizing and } \\
\text { increasing the transparency of governmental actions to society. }\end{array}$ \\
\hline CGE-RN & Serving as the central body of the Integrated System of Internal Control for the State of Rio Grande do Norte. \\
\hline CGE-SE & $\begin{array}{l}\text { Guiding public management and performing effective internal control of public property to safeguard the state } \\
\text { administration and to ensure that the interest of society is upheld. }\end{array}$ \\
\hline
\end{tabular}

Note: Reference year: 2008.

Similar to the disclosure of missions, for the disclosure of visions, the main idea was related to control (see Table 5). However, the small number of responses restricted our ability to establish other comparisons. 
Table 5. Vision of the public controllership institutions

\begin{tabular}{ll}
\hline INSTITUTION & VISION \\
\hline CGE-MA & $\begin{array}{l}\text { Becoming a strategic factor in public policy management, harmonizing the roles of control and education, } \\
\text { strengthening institutional partnerships, and aiming to optimize the overall results. }\end{array}$ \\
\hline CGE-SE & $\begin{array}{l}\text { Being recognized by } 2010 \text { as a reference for the internal control of a state's public property, whose activities } \\
\text { will be integrated with social control and external control to ensure the excellence of public management. }\end{array}$ \\
\hline
\end{tabular}

Note: Reference year: 2008.

The 'Transparency Portal' (Brasil, 2005) (in Portuguese: 'Portal da Transparência') is a website created and maintained by the CGU to disseminate information on the use of public resources and governmental action. It aims to increase the transparency of public management, social control, and the struggle against corruption. The Transparency Portal provides information on the following: 1) expenses incurred directly by the federal government; 2) transfers to subnational governments; 3) agreements by the Union; and 4) the credit operations of the Union.

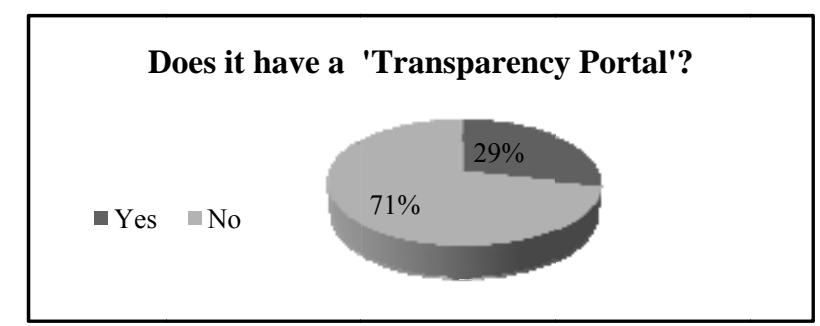

Source: Survey data (2008).

Figure 6. Existence of the site called 'Transparency Portal'

Referencing the data presented in Figure 6, we noted that only $29 \%$ of the public entities that have a public controllership have a specific website designed to disseminate information about the management of the state entity in a format similar to the 'Transparency Portal' of CGU.

Next, we examined the activities of these institutions, which are listed in Table 6.

Table 6. Activities of the public controllership institutions

\begin{tabular}{|c|c|c|c|c|c|c|c|c|c|c|c|c|c|c|c|}
\hline \multicolumn{2}{|c|}{ ACTIVITY } & \multirow{2}{*}{$\frac{0}{0}$} & 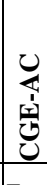 & 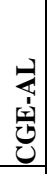 & 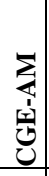 & 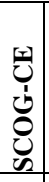 & 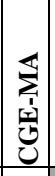 & $\begin{array}{l}0 \\
0 \\
1 \\
0 \\
0 \\
0\end{array}$ & 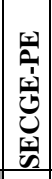 & $\begin{array}{l}\overline{1} \\
\text { 工⿱士口 } \\
0 \\
0\end{array}$ & \multicolumn{2}{|c|}{ 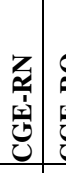 } & 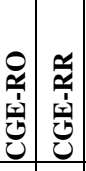 & $\begin{array}{l}\text { T1 } \\
\text { 1 } \\
\text { 寽 } \\
0 \\
\end{array}$ & $\begin{array}{l}0 \\
\vdots \\
\vdots \\
\vdots \\
0 \\
0 \\
0 \\
0\end{array}$ \\
\hline 01 & Monitoring/supervising administrative/operational management. & & & a & 口 & - & a & & - & $\square$ & - & - & $\square$ & a & - \\
\hline 02 & Monitoring/supervising accounting, financial, and budgetary management. & - & a & a & - & - & a & - & - & $\square$ & - & - & $\square$ & - & - \\
\hline 03 & Monitoring/supervising the asset management. & - & a & $\mathbf{a}$ & - & - & $\mathbf{a}$ & & 口 & $\square$ & 口 & - & 口 & $\square$ & - \\
\hline 04 & Supporting the organs of external control. & & & a & $\square$ & - & & $\square$ & - & $\square$ & $\square$ & $\square$ & & $\square$ & $\square$ \\
\hline 05 & Evaluating the implementation of management contracts. & & & & & - & & & & & & & & & \\
\hline 06 & Evaluating the results of plans and budgets. & & & a & & $\square$ & & & - & & & 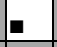 & & - & $\square$ \\
\hline 07 & Creating conditions for the exercise of social control. & - & & & & - & a & & ! & $\square$ & & & & & \\
\hline 08 & Preparing financial statements. & & & & & & & & & & ! & - & & & \\
\hline 09 & Developing and maintaining an updated chart of accounts. & & & & & & & & & & - & - & & & \\
\hline 10 & Managing the accounts. & & & & & & & 口 & & & & - & & & \\
\hline 11 & Planning, coordinating, and performing internal control. & - & ! & a & - & - & ! & - & - & $\square$ & - & - & $\square$ & - & - \\
\hline 12 & Planning, coordinating, and executing functions of internal affairs. & - & 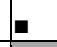 & a & & & & & & & & & & & \\
\hline 13 & Planning, coordinating, and performing as an ombudsman. & - & & & & - & & & & $\square$ & & & & & \\
\hline 14 & Preventing and combating corruption. & - & & & & & & & - & & & & & & \\
\hline 15 & Promoting the transparency of public sector actions. & $\square$ & & & - & & & & - & & & & & & - \\
\hline 16 & Proposing measures to rationalize the use of public resources. & & & & & - & & & - & & & & & & \\
\hline 17 & Supervising taxes and expenditures. & & & & - & & - & & - & & & - & $\square$ & $\square$ & - \\
\hline 18 & Ensuring compliance with the principles of public administration. & & I & & & - & a & (1) & I & & I & I & I & . & I \\
\hline
\end{tabular}

Legend: - - presence of activity; - lack of activity.

Note: Reference year: 2008. 
All of the analyzed institutions engaged in 'monitoring/supervising accounting, financial, and budgetary management' and 'planning, coordinating, and performing internal control.' In contrast, only a single institution (SCOG-EC) engaged in 'evaluating the implementation of management contracts.' The most common activities of these institutions are shown in Figure 7.

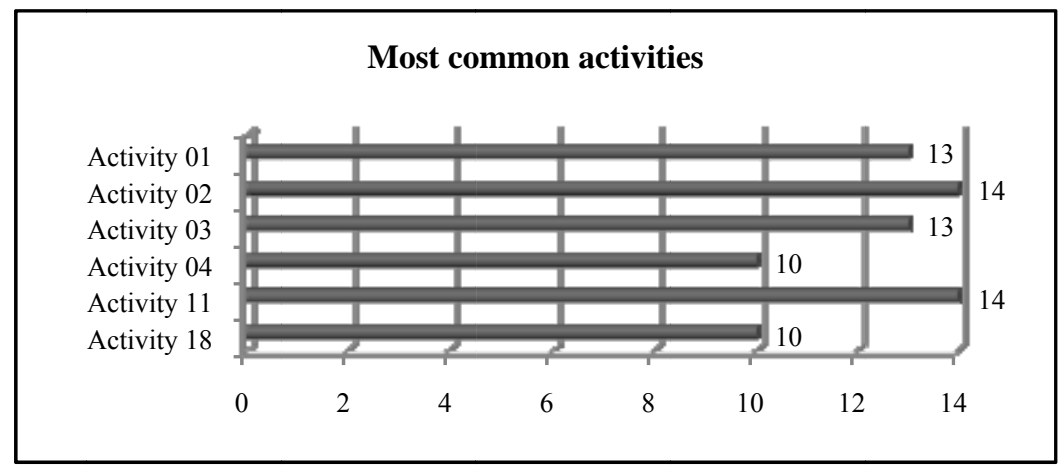

Figure 7. Most common activities

In Table 7, the activities identified and listed in Table 6 are classified into the typical functions of controllership in accordance with the concepts presented earlier in this paper.

Table 7. Activities grouped according to functions

\begin{tabular}{|c|c|}
\hline FUNCTION & ACTIVITY \\
\hline Accounting & $\begin{array}{l}\text { - } \quad \text { Monitoring/supervising the accounting, financial, and budgetary management. } \\
\text { - } \quad \text { Preparing financial statements. } \\
\text { - } \quad \text { Managing the accounts. }\end{array}$ \\
\hline Strategic management & $\begin{array}{l}\text { - } \quad \text { Monitoring/supervising the administrative/operational management. } \\
\text { - } \quad \text { Evaluating the results of plans and budgets. } \\
\text { - } \quad \text { Proposing measures to rationalize the use of public resources. }\end{array}$ \\
\hline Tax & - $\quad$ Supervising taxes and expenditures. \\
\hline $\begin{array}{l}\text { Protection and control of } \\
\text { assets }\end{array}$ & - $\quad$ Monitoring/supervising the asset management. \\
\hline Internal control & $\begin{array}{l}\text { - } \quad \text { Supporting the organs of external control. } \\
\text { - } \quad \text { Planning, coordinating, and performing internal control. } \\
\text { - } \quad \text { Planning, coordinating, and executing the functions of internal affairs. } \\
\text { - } \quad \text { Planning, coordinating, and performing as an ombudsman. } \\
\text { - }\end{array}$ \\
\hline Risk control & $\begin{array}{l}\text { - } \quad \text { Evaluating the implementation of management contracts. } \\
\text { - } \quad \text { Preventing and combating corruption. }\end{array}$ \\
\hline Information management & $\begin{array}{l}\text { - } \quad \text { Creating conditions for the exercise of social control. } \\
\text { - } \quad \text { Promoting the transparency of public sector actions. }\end{array}$ \\
\hline
\end{tabular}

Note: Reference year: 2008.

When the activities assigned to the analyzed institutions were organized according to their most characteristic features, we noted the existence of seven functions that were performed by the public controllership institutions. Initially, we found that the only undiscovered function was the cost function.

Table 8. Function x Activities

\begin{tabular}{lll}
\hline FUNCTION & NUMBER OF ACTIVITIES \\
\hline Accounting & 4 & $22.2 \%$ \\
Strategic management & 3 & $16.8 \%$ \\
Tax & 1 & $5.6 \%$ \\
Protection and control of assets & 1 & $5.6 \%$ \\
Internal control & 5 & $27.8 \%$ \\
Risk control & 2 & $11.0 \%$ \\
Information management & 2 & $11.0 \%$ \\
\hline Total & 18 & $100.0 \%$ \\
\hline
\end{tabular}

Note: Reference year: 2008. 
Comparing the functions with the classification of activities, we noted that the 'internal control' function received greater emphasis compared with the others. The group formed by the 'accounting,' 'strategic management,' and 'internal control' functions comprised $66.8 \%$ of all activities conducted by the public controllership institutions. In contrast, the 'protection and control of assets' and 'tax' functions, which represented $11.2 \%$ of all activities listed in Table 6 , were rarely performed.

Table 9. Function $\mathrm{x}$ Institutions

\begin{tabular}{llc}
\hline FUNCTION & \multicolumn{2}{l}{ NUMBER OF INSTITUTIONS } \\
\hline Accounting & 14 & $100.0 \%$ \\
Strategic management & 13 & $92.8 \%$ \\
Tax & 7 & $50.0 \%$ \\
Protection and control of assets & 13 & $92.8 \%$ \\
Internal control & 14 & $100.0 \%$ \\
Risk control & 3 & $21.4 \%$ \\
Information management & 7 & $50.0 \%$ \\
\hline
\end{tabular}

Note: Reference year: 2008.

Considering only the number of institutions that performed at least one activity related to the functions typical of the controllership, we noted that all institutions performing activities were linked to the 'accounting' and 'internal control' functions. The functions of 'strategic management' and 'protection and control of assets' were performed by 13 institutions. We also observed that the 'risk control' function was performed by $21.4 \%$ of the analyzed institutions.

Table 10. Function $\mathrm{x}$ Institutions and activities

\begin{tabular}{llc}
\hline FUNCTIONS & NUMBER OF EVENTS \\
\hline Accounting & 20 & $17.7 \%$ \\
Strategic management & 21 & $18.6 \%$ \\
Tax & 7 & $6.2 \%$ \\
Protection and control of assets & 13 & $11.5 \%$ \\
Internal control & 40 & $35.4 \%$ \\
Risk control & 3 & $2.6 \%$ \\
Information management & 9 & $8.0 \%$ \\
\hline Total & 113 & $100.0 \%$ \\
\hline
\end{tabular}

Note: Reference year: 2008.

By comparing the activities assigned to the institutions while considering the function to which it relates and the likelihood of occurrence in the analyzed institutions, we could argue that the 'internal control' function was performed in most of the Brazilian public controllership institutions. According to the data in Table 10, the 'accounting,' 'strategic management,' and 'internal control' functions comprised $71.7 \%$ of the public controllership institutions' total activities. In contrast, the functions of 'risk control,' 'tax,' and 'information management' corresponded to $16.8 \%$ of the assigned activities.

\section{Conclusions}

In the public sector, the controllership plays an important role because it not only assists in the decision-making process but also allows public managers to develop mechanisms to monitor public activities and programs. This study attempted to analyze the structure and functions of the public controllership in the Brazilian context.

We compared the controllership functions identified as typical in the literature with the functions performed by Brazilian public institutions that were officially named as part of the controllership. We analyzed 14 public institutions, with the majority of these institutions created less than six years ago. All of them were part of the executive branch, were subordinate to the head of this power, and were organized as Secretaries (Ministry, in the case of (GU) or as autonomous institutions.

Based on the analysis of the activities performed by the institutions according to their legal regulations, we found evidence of all typical controllership functionsother than the cost function. Because these data suggest that the functions performed by the Brazilian public controllership institutions are not different from the controllership functions defined by the authors, the analyzed data disproved the hypothesis presented in this article. 
Although at least one activity of each government controllership authority was detected for each function, the 'internal control' function distinguished itself from the other functions, mainly because many institutions had been established as the central organ of internal control. We also noted that, although there was no difference between the functions of the institutions and those defined in the literature, the activities assigned to the public controllership institutions were rarely performed in all functions other than internal control.

The analysis undertaken in this article provides an introduction to studies on the public controllership in Brazil and enables the features of the institutions included in this context to be identified. We suggest that future research increase the number of analyzed entities and/or characteristics.

\section{References}

Almeida, L. B., Parisi, C., \& Pereira, C. A. (1999). Controladoria. In Catelli, A. (Ed.), Controladoria: uma abordagem da gestão econômica - GECON (pp. 369-381). São Paulo: Atlas.

Borinelli, M. L. (2006). Estrutura conceitual básica de controladoria: sistematização à luz da teoria e da práxis. (Doctoral dissertation). University of São Paulo, São Paulo, Brasil.

Brasil. (2005). Decreto n. ${ }^{\circ}$ 5.482, de 30 de junho de 2005. Dispõe sobre a divulgação de dados e informações pelos órgãos e entidades da administração pública federal. Diário Oficial da República Federativa do Brasil, Brasília.

Consejo da la Judicatura Federal. (2008). Órganos Auxiliares del Conselho de la Judicatura Federal. Retrieved Ago 2, 2008, from http://www.cjf.gob.mx/ orgauxiliares.htm.

Crozatti, J. (2003). Planejamento Estratégico e Controladoria: um modelo para potencializar a contribuição das áreas da organização. Contexto, Porto Alegre, 5(1), 123-147.

Gasparini, D. (2002). Direito administrativo (7th ed.). São Paulo: Saraiva.

Green, B. P., \& Kaplan, J. (2004). Controllership: The Other Accounting Career. New Accountant Magazine, 709.

International Federation of Accountants. (2001). Governance in the Public Sector: A Governing Body Perspective, 13, 1-85.

Mosimann, C. P., \& Fisch, S. (1999). Controladoria: seu papel na administração de empresas (2nd ed.). São Paulo: Atlas.

Peleias, I. R. (2002). Controladoria: gestão eficaz utilizando padrões. São Paulo: Saraiva.

Peter, M. G. A., Cavalcante, M. C. N., Pessoa, M. N. M, Santos, S. M., \& Peter, F. A. (2003). A controladoria e a gestão pública: A experiência do governo do estado do Ceará. Proceedings of Congresso del Instituto Internacional de Costos, Punta del Este,1-20.

Piai, M. A. B. (2000). Metodologia para implementação de sistema de Controladoria. (Master's degree dissertation). Federal University of Santa Catarina, Florianópolis.

Scarpin, J. E., \& Slomski, V. (2007). Estudo dos fatores condicionantes do índice de desenvolvimento humano nos municípios do estado do Paraná: instrumento de controladoria para a tomada de decisões na gestão governamental. Revista de Administração Pública, 5(41), 909-933. http://dx.doi.org/10.1590/S0034-76122007000500006

Slomski, V. (2001). Manual de contabilidade pública: um enfoque na contabilidade municipal. São Paulo: Atlas.

Slomski, V. (2007). Controladoria e governança na gestão pública. São Paulo: Atlas.

Solle, G. (2003). Dispositifs de contrôle de gestion et établissements publics d'enseignement: Une vision trop instrumentale. Revue Électronique de Management Public, Nice. Retrieved Ago 2, 2008 from http://www.unice.fr/ recemap/.

Thompson, F., \& Jones, L. R. (1986). Controllership in the Public Sector. Journal of Policy Analysis and Management, 5(3), 547-571. http://dx.doi.org/10.1002/pam.4050050309

Tung, N. H. (1976). Controladoria financeira das empresas - uma abordagem prática (5th ed.). São Paulo: Editora da Universidade de São Paulo.

Willson, J. D., Roehl-Anderson, J. M., \& Bragg, S. M. (1997). Controllership: The Work of the Managerial Accountant (5th ed.). New York: John Wiley \& Sons Inc. 